\title{
PENGARUH EKSTRAK DAUN SIRSAK (Annona muricata Zinn) TERHADAP PERKEMBANGAN LARVA Aedes aegypti
}

\author{
Susiwati \\ Politeknik Kesehatan Kementrian Kesehatan Bengkulu, Jurusan Analis Kesehatan \\ Jl. Indragiri No.3 Padang Harapan Kota Bengkulu \\ jmkbengkulu@gmail.com
}

\begin{abstract}
Soursop plants is a plant that is widely available in Indonesia. In addition to fruit that can be directly consumed. The main content of soursop is active compounds annonaceus acetogenin. The leaves are most part annonaceus acetogenin containing compounds that are known to have the effect of insecticide, antifeedant repelant and works as a contact and stomach poison toxin in Aedes aegypti larvae. The purpose of this study was to determine the effect of extract of soursop's leaves (Annona muricata Zinn) as larvicides of Aedes aegypti in different levels of concentrations. This research is quasi-experimental. The samples used were 600 instar larvae of Aedes aegypti III/IV. Each treatment containing 25 larvae and repetition as much as 4 times. Soursop leaf extract concentration tested, namely $0 \%$ (control), 5\%, 10\%, 15\%, 20\%, and 25\%. The result is the number of Aedes aegypti larvae were dead after 24 hours in each concentration group. Greatest death in a concentration of $25 \%$ is as much as $92 \%$, while the lowest mortality at a concentration of $5 \%$ is as much as $15 \%$. The results of the study were further tested with One Way Anova. Statistical test results obtained with One Way Anova sig. $=0.000$ so that $\rho<\alpha(0.05)$ means that there is a significant effect on the difference in average number of larvae mortality in each treatment group because of increasing the concentration. LSD test results showed a mean difference significant at the 0.05 level. From the results of this research community can use extract of soursop's leaves with a concentration of $25 \%$ as an alternative to eradication of Aedes aegypti is a vector of Dengue Fever (DHF). Further research needs to be done on the toxicology and safety of soursop leaf extract as an alternative to the eradication of Aedes aegypti mosquito larvae.
\end{abstract}

Keywords : Extract of soursop's leaves, Aedes aegypti, and Larvicides

ABSTRAK Tanaman Sirsak merupakan tanaman yang banyak terdapat di Indonesia. Selain buahnya yang dapat langsung dikonsumsi. Kandungan utama sirsak adalah senyawa aktif annonaceus acetogenin. Daunnya merupakan bagian yang terbanyak mengandung senyawa annonaceus acetogenin yang diketahui mempunyai efek insektisida, repelant dan antifeedant yang bekerja sebagai racun kontak dan racun perut pada larva Aedes aegypti. Penelitian ini bertujuan untuk mengetahui pengaruh ekstrak daun sirsak (Annona muricata linn) sebagai larvasida Aedes aegypti dalam berbagai tingkat konsentrasi. Jenis penelitian ini adalah quasi eksperimen. Sampel yang digunakan adalah 600 ekor larva Aedes aegypti instar III/IV. Masing-masing perlakuan berisi 25 ekor larva dan dilakukan pengulangan sebanyak 4 kali. Konsentrasi ekstrak daun sirsak yang dicobakan yaitu 0\% (kontrol), 5\%, 10\%, 15\%, 20\%, dan $25 \%$. Hasil yang diperoleh adalah jumlah larva Aedes aegypti yang mati setelah 24 jam pada tiap-tiap kelompok konsentrasi. Kematian terbesar pada konsentrasi $25 \%$ yaitu sebanyak $92 \%$, sedangkan kematian paling rendah pada konsentrasi $5 \%$ yaitu sebanyak $15 \%$. Hasil penelitian selanjutnya diuji dengan One Way Anova. Hasil uji statistik dengan One Way Anova didapatkan nilai sig. $=0,000$ sehingga $\rho<\alpha(0,05)$ berarti ada pengaruh yang signifikan terhadap perbedaan rata-rata jumlah kematian larva pada tiap kelompok perlakuan karena adanya peningkatan konsentrasi. Hasil uji LSD menunjukan adanya perbedaan rata-rata yang signifikan pada level 0,05. Dari hasil penelitian ini masyarakat dapat menggunakan ekstrak daun sirsak dengan konsentrasi 25\% sebagai alternatif pemberantasan larva Aedes aegypti yang merupakan vektor penyakit Demam Berdarah (DBD) sebanyak 92\%. Perlu dilakukan penelitian lebih lanjut mengenai toksikologi dan keamanan dari ekstrak daun sirsak sebagai alternatif pemberantasan larva nyamuk Aedes aegypti.

Kata Kunci : Ekstrak daun sirsak, Aedes aegypti, dan Larvasida 
Indonesia sebagai negara tropik mempunyai kelembaban dan suhu optimal yang menguntungkan bagi kelangsungan hidup, pertumbuhan larva, dan penularan parasit. Oleh karenanya, penyakit yang disebabkan oleh parasit banyak dijumpai. Penularannya dapat melalui kontak langsung atau tidak langsung, melalui makanan, air, tanah, hewan vertebrata, dan vektor arthropoda (Lane, 2005), salah satunya adalah penyakit Demam Berdarah Dengue. Penyakit Demam Berdarah. Dengue (DBD) di Indonesia sampai saat ini masih merupakan masalah kesehatan masyarakat yang serius karena banyak daerah yang endemik. Penyakit DBD ini belum ditemukan obat antiviral spesifiknya dan belum ada vaksin antidengue yang efektif dan komersial sehingga wajar kasus dan kematian akibat DBD di Indonesia meningkat setiap tahun. Di Indonesia kasus DBD pertama kali terjadi di Surabaya pada tahun 1968 dan sekarang telah menyebar keseluruh provinsi di Indonesia (Soedarto, 2008). Selama Januari hingga September 2013, terjadi $1.991 \mathrm{ka}-$ sus DBD di Jakarta Selatan. Angka ini lebih tinggi dari kasus yang terjadi pada tahun sebelumnya, sebanyak 1.601 kasus. Di Bengkulu terhitung sejak Januari 2013 hingga April 2013 terdapat 75 kasus, sementara yang meninggal dunia belum ada (Dinkes, 2013).

Pengendalian nyamuk bisa dilakukan dengan berbagai cara yaitu pengendalian secara mekanis, biologis, dan kimiawi. Salah satu pengendalian nyamuk yang paling sederhana dan sering dilakukan masyarakat adalah secara kimiawi atau menggunakan insektisida. Namun, pemberantasan nyamuk dengan menggunakan insektisida kimia telah banyak menimbulkan dampak negatif antara lain peningkatan resistensi nyamuk, pencemaran lingkungan, keracunan, kematian makhluk bukan residu (Murtanti dan Astuti, 2005).

Menurut Soedarto (2008), saat ini penggunaan pestisida kimia di Indonesia dan seluruh dunia masih tinggi di ber- bagai sektor pembangunan, seperti sektor pertanian dan kesehatan. Dari hasil kegiatan deteksi dan monitoring, resistensi jumlah dan keragaman jenis serangga yang menunjukkan fenomena ketahanan terhadap satu atau beberapa jenis atau kelompok pestisida semakin meningkat. Setiap jenis organisme, termasuk Aedes aegypti, mempunyai kemampuan mengembangkan populasi tahan terhadap pestisida. Ketahanan di lapangan diindikasikan oleh menurunnya efektivitas pengendalian dengan pestisida. Proses seleksi pengembangan ketahanan pestisida tidak terjadi dalam waktu singkat, tetapi berlangsung selama banyak generasi yang diakibatkan oleh perlakuan pestisida secara terus-menerus.

Insektisida adalah bahan kimia yang digunakan untuk memberantas serangga. Untuk memilih jenis insektisida harus memperhatikan berbagai faktor agar tepat sasaran dan tidak menimbulkan dampak negatif misalnya pencemaran lingkungan. Salah satunya adalah menggunakan insektisida sintesis, yaitu menggunakan bahan alami yang berasal dari tumbuhan akar, batang, daun, buah, atau biji (Soedarto, 2008)

Sirsak merupakan tanaman yang banyak terdapat di Indonesia. Selain buahnya yang dapat langsung dikonsumsi, bagian lain dari pohon sirsak seperti kulit kayu, daun, biji dan akar dapat dimanfaatkan sebagai tanaman obat untuk mengobati berbagai penyakit, insektisida, larvasida, molluscida, antimikroba dan lain-lain. Daunnya merupakan bagian yang terbanyak mengandung senyawa annonaceus acetogenin, daun sirsak juga mengandung bahan aktif lainnya seperti annonain, saponin, flavonoid, dan tanin. Kandungan senyawa annonaceus acetogenin yang terdapat dalam daun sirsak tersebut diketahui mempunyai efek insektisida, repelant dan antifeedant yang bekerja sebagai racun kontak dan racun perut (Kardinan, 2003).

Menurut Baskoro (2007), pemberantasan nyamuk Aedes aegypti yang merupakan vektor potensial penyakit Demam Berdarah 
Dengue (DBD) dengan menggunakan insektisida telah banyak menimbulkan dampak negatif, antara lain peningkatan resistensi nyamuk, pencemaran lingkungan, keracunan, kematian mahluk bukan sasaran dan terbentuknya residu. Oleh karena itu, perlu dicari alternatif lain untuk membasmi nyamuk, yaitu dengan menggunakan bioinsektisida nabati.

Senyawa-senyawa bioaktif dari daun sirsak, selain toksik terhadap serangga, juga mudah mengalami biodegradasi dari alam, sehingga tidak berbahaya bagi lingkungan. Perlu adanya penelit ian lebih lanj ut mengenai keamanan penggunaannya agar dapat dipergunakan secara luas di masyarakat. Oleh karena itu, penulis tertarik untuk melakukan penelitian tentang "Pengaruh Ekstrak Daun Sirsak (Annona muricata linn) Terhadap Perkembangan Larva Aedes aegypti Di Kota Bengkulu Tahun 2014”.

Dari latar belakang di atas maka penulis menyimpulkan rumusan masalah apakah ekstrak daun sirsak (Annona muricata linn) mempunyai pengaruh terhadap perkembangan larva A. aegypti dan pada konsentrasi berapa persen ekstrak daun sirsak (Annona muricata linn) yang paling kuat dalam mematikan larva A. aegypti.

Penelitian ini bertujuan untuk mengetahui pengaruh ekstrak daun sirsak (Annona muricata linn) sebagai larvasida Aedes aegypti dalam berbagai tingkat konsentrasi.

\section{BAHAN DAN CARA KERJA}

Bahan yang digunakan adalah Aquadest, daun sirsak, dan etanol $70 \%$, Larva Nyamuk Anopheles sp instar III dengan alat gelas plastik bekas, kertas label, nampan, pisau, beker gelas, wadah plastik, kain penyaring, waterbath, labu ukur, pipet tetes, pipet ukur dan botol semprot. Cara penelitian dengan membuat wadah tempat nyamuk berkembangbiak yang mirip seperti tempat perindukan aslinya menggunakan wadah plastik bekas atau kaleng bekas (Ovitrap) dan meletakkan kertas saring di bagian pinggir dalam wadah. Wadah plastik tersebut diisi dengan air (3/4 dari isi penuh). Wadah plastik yang telah berisi air kemudian diletakkan di tempat-tempat yang gelap di dalam rumah.

Percobaan ini dengan membuat pengenceran ekstrak daun sirsak konsentrasi 0\% (kontrol), 5\%, 10\%, 15\%, 20\%, dan 25\% dimana tiap konsentrasi dilakukan pengulangan sebanyak empat kali. Pada tiaptiap konsentrasi ekstrak daun sirsak dimasukkan larva nyamuk sebanyak 25 ekor. Diamkan selama 24 jam kemudian amati jumlah larva yang mati pada tiap konsentrasi.

Hasil yang didapatkan ditulis dalam bentuk tabel. Pembuatan ekstrak daun sirsak dengan cara memilih daun sirsak ( $A n$ nona muricata linn) yang berwarna hi-jau tua kemudian dicuci bersih. Daun sirsak dikeringkan selama 7 hari tanpa terkena sinar matahari langsung. Daun sirsak yang sudah kering kemudian diiris halus. Irisan daun sirsak dicampur ke da-lam larutan etanol $70 \%$ pada wadah plas-tik. Setelahdilakukan pencampuran dilakukan perendaman selama 3-5 hari. Kemudian rendaman tersebut diperas dan disaring. Filtrat hasil perasan/saringan (ekstrak daun sirsak) kemudian dibuat residu dengan cara diuapkan diwaterbath pada suhu $40^{\circ \mathrm{C}}$ hingga volumenya berkurang dari volume awal. Residu dengan konsentrasi $100 \%$ tersebut kemudian diencerkan dengan aquadest untuk mendapatkan ekstrak daun sirsak dengan konsentrasi 0\% (kontrol), 5\%, 10\%, 15\%, $20 \%$, dan $25 \%$.

\section{HASIL}

\section{Analisis Univariat}

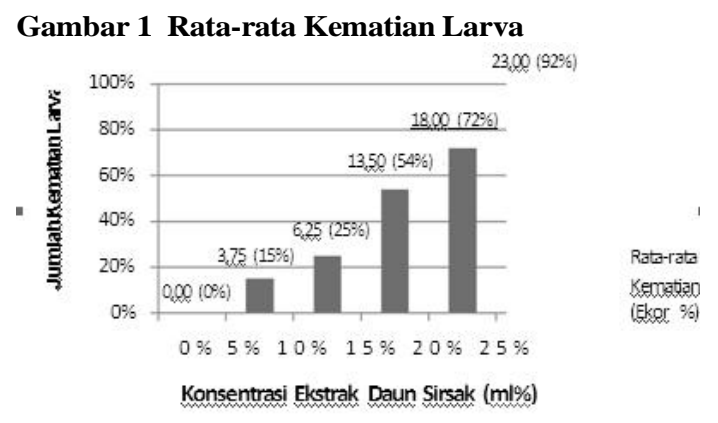

Hasil jumlah larva nyamuk Aedes aegypti yang mati dengan menggunakan ekstrak daun sirsak (Annona muricata l) konsentrasi 0\% (kontrol), 5\%, 10\%, 15\%, 
$20 \%$, dan $25 \%$ dengan 4 kali pengulangan terlihat pada gambar 1.

Tabel 1 rata- rata larva yang paling rendah mati pada konsentrasi 5\% sebanyak 4 ekor larva dengan standar deviasi 1,500 dan yang tertinggi pada konsentrasi $25 \%$ rata-rata larva yang mati sebanyak 23 ekor larva dengan standar deviasi 0,816. Hasil One Way Anova didapat nilai $\rho$ value $=0,000$ berarti pada alpha 5\% dapat disimpulkan bahwa Ho ditolak berarti bahwa ada perbedaan kematian larva Aedes aegypti berdasarkan perlakuan konsentrasi ekstrak daun sirsak yang dipaparkan.

Tabel 1 Hasil Uji Analisis One Way Anova

\begin{tabular}{cccccccc}
\hline Konsentrasi & Mean & SD & \multicolumn{3}{c}{$\mathbf{9 5 \%}$ CI } & N P-value \\
\cline { 3 - 6 } & & \multicolumn{4}{c}{$\begin{array}{c}\text { Lower } \\
\text { Bound }\end{array}$} & $\begin{array}{c}\text { Upper } \\
\text { Bound }\end{array}$ & \\
& & & & & & \\
\hline $5 \%$ & 3,75 & 1,500 & 1,36 & 6,14 & 4 & 0,000 \\
$10 \%$ & 6,25 & 1,258 & 4,25 & 8,25 & 4 & \\
$15 \%$ & 13,50 & 1,291 & 11,45 & 15,55 & 4 & \\
$20 \%$ & 18,00 & 0,816 & 16,70 & 19,30 & 4 & \\
$25 \%$ & 23,00 & 0,816 & 21,70 & 24.30 & 4 & \\
\hline
\end{tabular}

Tabel 4.2 Hasil Uji Multiple Comparison (LSD)

\begin{tabular}{cr}
\hline $\begin{array}{c}\text { Konsentrasi } \\
\text { Ekstrak Etanol Daun Sirsak }\end{array}$ & $\begin{array}{c}\text { Rata-rata kematian } \\
\text { larva }\end{array}$ \\
\hline 5 & $3.75^{\mathrm{a}}$ \\
10 & $6.25 \mathrm{~b}$ \\
15 & $13.50 \mathrm{c}$ \\
20 & $18.00 \mathrm{~d}$ \\
25 & $23.00 \mathrm{e}$ \\
\hline
\end{tabular}

Kematian larva yang terjadi dari setiap perlakuan konsentrasi ekstrak daun sirsak menunjukkan adanya perbedaan yang signifykan, perbedaan ini dapat dilihat dari uji lanjutan yaitu Analisis Multiple Com-parison, Least Significant Difference (LSD) pada Tabel 2.

\section{PEMBAHASAN}

Hasil penelitian diketahui bahwa semakin besar konsentrasi maka semakin besar juga kematian larva Aedes aegypti. Artinya dari hasil penelitian ini membuktikan bahwa ekstrak daun sirsak efektif terhadap kematian larva Aedes aegypti dengan adanya peningkatan konsentrasi ekstrak daun sirsak.

Daun sirsak mengandung bahan ak- tif annonain, saponin, flavonoid dan tanin (Kardinan, 2004). Bahkan Naria (2005), menyatakan bahwa pada sirsak ditemukan senyawa bersifat bioaktif yang dikenal dengan nama acetogenins (bulatacin, asimisin, dan squamosin). Acetogenins dalam senyawa yang tinggi berfungsi sebagai antifeedent. Hama sekalipun enggan memakan daun sirsak meskipun dalam konsentrasi rendah karena bisa menyebabkan hama atau serangga tersebut mati. Senyawa acetogenin pada konsentrasi yang tinggi akan bersifat antifeedant bagi serangga, sehingga menyebabkan serangga tidak mau makan. Pada konsentrasi rendah dengan pemberian oral bersifat racun perut dan dapat menyebabkan kematian (Naria, 2005).

Larva yang mati dalam percobaan memperlihatkan tanda-tanda yaitu larva tidak bergerak sama sekali, tubuhnya berwarna putih, kaku dan berada di dasar air (Ani et al., 2010). Larva yang digunakan dalam penelitian ini adalah larva instar 3 dan 4 karena pada stadium ini ukurannya paling besar sehingga sistem pertahanannya lebih kuat dari pada larva instar 1 dan 2. Dengan demikian diperkirakan bahwa ekstrak yang mampu membunuh larva instar 3 dan 4 juga mampu membunuh larva instar 1 dan 2 (Agnetha, 2010).

Hasil penelitian terlihat dengan jumlah banyaknya larva Aedes aegypti yang mati dengan adanya variasi konsentrasi ekstrak daun sirsak. Dengan meningkatnya konsentrasi ekstrak daun sirsak maka semakin meningkat pula jumlah kematian larva. Sehingga ekstrak daun sirsak ini dapat dikatakan sebagai larvasida.

Pada kelompok kontrol 0\% larva hanya diberi aquadest. Ini dilakukan untuk melihat kemungkinan larva mati yang disebabkan oleh aquadest. Hasil pengujian menunjukkan konsentrasi ekstrak da-un sirsak $25 \%$ pada penelitian yang telah dilakukan adalah konsentrasi yang paling efektif untuk membunuh larva $A e$ - 
des aegypti karena dapat membunuh larva sebanyak 92\%, dikatakan efektif apabila mampu membunuh lebih dari $75 \%$ larva. Sedangkan pada konsentrasi terendah yaitu 5\% sebanyak 15\% kematian larva. Peningkatan kematian larva Aedes aegypti pada penelitian ini menunjukkan kecenderungan bahwa semakin tinggi ekstrak daun sirsak maka jumlah kematian larva Aedes aegypti juga semakin tinggi. Hal ini serupa dengan penelitian oleh Sudjari et al., (2006), dimana jumlah kematian larva Culex sp. Sebanding dengan naiknya konsentrasi ekstrak biji sirsak (Annona muricata linn), dengan hasil yaitu kematian terkecil $15 \%$ pada konsentrasi 100 ppm dan kematian terbesar $100 \%$ pada konsentrasi 1000 ppm. Senyawa aktif yang bersifat insektisida yang terdapat dalam daun sirsak diketahui mempunyai efek repelant dan antifeedant yang bekerja sebagai racun kontak dan racun perut (Kardinan, 2003). Senyawa tersebut masuk ke dalam organ pencernaan larva kemudian menyebabkan kerusakan jaringan, sehingga larva gagal melakukan absorbsi zat makanan yang dapat menyebabkan larva menjadi malnutrisi lalu menyebabkan kematian pada larva Aedes aegypti.

Dari hasil penelitian menunjukkan bahwa penggunaan ekstrak daun sirsak memiliki kemampuan terhadap kematian larva Aedes aegyptiyang dapat dilihat ber-

\section{Daftar Rujukan}

Agnetha, 2010. Efek Ekstrak Bawang Putih (Allium sativum l) sebagai larvasida nyamuk aedes sp. Fakultas Kedokteran Universitas Brawijaya, Malang.

Ani et al., 2010. Siklus Hidup Larvasida Alami Aedes aegypti dalam Upaya Pemberantasan Demam Berdarah Dengue, Yayasan Pembina Lembaga Pendidikan Dasar dan Menengah PGRI (Y PL P DASM EN PGRI) Kota Bekasi, Bekasi.

Astari S, Ahmad I. 2005. Insecticide Resistance and Effect of Piperonyl Butoxide as a Synergist in Three Strain nof Aedes aegypti (Linn) (Diptera: Cullicidae) on Insecticide Permethrin, Sypermethrin, and $d$ - Allethrin. Bul. Penel. Kesehatan Vol 33 No 2: 73 - 79.

Baskoro T, Nalim S, 2007. Pengendalian Nyamuk dasarkan peningkatan jumlah kematian larva serta ada pengaruh ekstrak daun sirsak terhadap perkembangan larva Aedes aegypti karena semakin tinggi kematian larva maka semakin kecil peluang keberhasilan larva menjadi pupa atau pupa dewasa. Dengan demikian penggunaan ekstrak daun sirsak mempunyai dasar untuk digunakan sebagai larvasida alami karena kandungan senyawa aktif yang bersifat insektisida yang tekdapat di dalam daun sirsak cukup efektif dalam membunuh larva Aedes aegypti (Astari, 2005).

\section{KESIMPULAN}

Hasil penelitian disimpulkan bahwa terdapat pengaruh ekstrak daun sirsak terhadap perkembangan larva Aedes aegypti karena semakin tinggi kematian larva maka semakin kecil peluang keberhasilan larva menjadi pupa atau pupa dewasa dan konsentrasi yang paling efektif dalam mematikan larva Aedes aegypti adalah konsentrasi $25 \%$ dengan jumlah kematian sebesar 92\% sehingga dapat digunakan sebagai dasar untuk pengendalian vektor nyamuk Aedes aegypti. Untuk jangka panjang, daun sirsak dapat digunakan sebagai larvasida botani, yang efektif dalam pengendalian vektor nyamuk Aedes aegypti.

Penular Demam Berdarah Dengue di Indonesia. Makalah disampaikan dalam Simposium Demam Berdarah Dengue. Universitas Gadjah Mada Yogyakarta.

Badan Pusat Statistik. 2012. Produksi Sayur dan Buah Provinsi Bengkulu, hal :86. diakses pada 28/11/2013.

Dinas Kesehatan Provinsi Bengkulu. Laporan Kasus

172 Jurnal Media Kesehatan, Volume 8 Nomor 2, Oktober 2015, hlm 100-

kognosi) Jilid 1.Jakarta : Penebar Swadaya. Harborne, J.B. 2002. Intruduction to Ecological Biochemistry. Second Edition. Academic Press, New York, hal:66-67. Harborne, J.B. 2007. Metode Fitokimia ; PenuntunCara Modren Menganalisis 1 Kardinan, A. 2003. Tanaman Pengusir dan Pem- 
basmi Nyamuk. Penerbit Agro Media Pustaka, Jakarta, hal:18 - 31.

Kardinan, A. 2004. Pestisida Nabati Ramuan dan Aplikasi. Penebar Swadaya, Yogyakarta : hlm. 30.

Lane R, Crosskey. 2005. Medical Insect and Archnids, Rep. of Entomologi Chapman and Hall, London UK.

Nazir, M. 2003. Metode Penelitian, Penerbit Ghalia Indo, Jakarta.

Murtanti, D \& Astuti, U.N.W. 2005. Pengaruh Ekstrak-Etanol Daun Mindi, Melia azedarach L. Terhadap Daya Tetas Telur, Perkembangan Dan Mortalitas Larva Aedes albopictus. Forum MIPA. Volume 4, Nomor 1: hlm. 13.

Naria, E. 2005. Insektisida Nabati Untuk Rumah Tangga. Info Kesehatan Masyarakat. Volume IX, Nomor I. Penerbit FKM USU : 28-31.

Sembel, D.T. 2009. Entomologi Kedokteran, Penerbit ANDI, Yogyakarta.

Sembel, D.T. dan J. M. Wantania. 2002. Survei Penyebaran dan TempatTempat Pembiakan
Aedes aegypti, Vektor Penyakit Demam Berdarah, Fakultas Pertanian, Universitas Sam Ratulangi, Manado.

Soebaktiningsih. 2008. Penggunaan Bakteri Entomopatogenik dalam Pengendalian Nyamuk Anopheles, Aedes dan Culex. Bagian Parasitologi FK-Univ.Brawijaya, Penerbit Medika, Malang, hal:29-32.

Soedarto. 2008. Parasitologi Klinik, Penerbit Airlangga University Press, Surabaya.

Staf Edukatif Bagian Parasitologi. 1997. Panduan dan Buku Kerja Praktikum Parasitologi Kedokteran, FKUniv.Gadjah Mada, Yogyakarta.

Sudjari, Soemardini dan Hadiyanto, B. 2006. Efek Ekstrak Biji Sirsak (Annona muricata L) Sebagai Larvasida Culex sp, Jurnal Penelitian.

Yus, Y. 2006. Pengaruh Ekstrak Biji Annona muricata L Terhadap Indeks Nutrisi, Kelulushidupan, Pertumbuhan dan Perkembangan Larva Heliothis (Helicoverpa) armigera Hubner, Cetakan Ketujuh, M.S Tesis, Institut Teknologi Bandung, Bandung. 